\title{
Parenting Stress in the Parents with Mentally Retarded Children
}

\author{
Kumari Anjali, Prakash Jai, Kiran Manish
}

\begin{abstract}
Background: Parenting refers to the aspects of raising a child in terms of physical, social, emotional as well as over all development of the child aside from the biological relationship.

Aim: The present study has been undertaken with the aim to assess parenting stress in the parents of mentally retarded children and parents of normal healthy children.

Methods: A total of 100 respondents (50 parents of mentally retarded children and 50 parents of normal children) were selected by using purposive sampling technique. Further socio-demographic data sheet, General Health Questionnaire-12 and Parenting Stress Index Scale were administered.

Results: Parents of mentally retarded children showed parenting stress in comparison to parents of normal children. Parents of mentally retarded children had feeling of inability to handle things very easily. They feel trapped by their responsibilities as a parent. Parents of mentally retarded children showed parental distress and found to be having feeling that they are unable to do new and different things, they almost were unable to do things the way they like to do. They used to perceive that child rarely does things for them which make them feel good. They used to perceive that their child cry more than other children and generally wakes up in a bad mood and easily gets upset over the small things.
\end{abstract}

Conclusions: Parents with mentally retarded children showed stress in the areas related to defensive response, parental distress, parent child dysfunctional interaction and difficult child in comparison to parents of normal children.

Key words: Mentally retarded children, parental stress, defensive response and parent-child dysfunctional interaction.

\section{INTRODUCTION}

Parenting is the process of promoting and supporting the physical, emotional, social and intellectual development of a child from infancy to adulthood. Parenting refers to the aspects of raising a child aside from the biological relationship. Usually, parental figures provide for a child's physical needs, protect them from harm, and impart in them skills and cultural values until they reach legal adulthood. The degree of attention parents invest in their offspring is largely inversely proportional to the number of offspring the average adult in the species produces. Davies, Martin (2000) $)^{5}$

Raising a child who is mentally challenged requires emotional strength and flexibility. The child has special needs in addition to the regular needs of all children and parents can find themselves overwhelmed by various medical, caregiving and educational responsibilities whether the special needs of the child are minimal or complex, the parents are inevitably affected support from family, friends, the community or paid caregivers is critical to maintaining balance in the home.

Parents of mentally challenged children commonly experience a gamut of emotions over the years. They often struggle with guilt. Occasionally, parents feel embarrassed or ashamed that their child is mentally disabled. Physical exhaustion can take a toll on the parents of a mentally challenged child. The degree of physical exhaustion is usually related to the amount of care needed. The American Academy of family physician relates that these issues can cause significant caregiver stress. The parent of a child with developmental disabilities may have to deal with complex issues related to education. Raising a child with a mental challenge may be more expensive than raising a typical child. These expenses can arise from medical equipment and supplies, medical care, caregiving expenses, private education, tutoring, adaptive learning equipment or specialized transportation. 
Gath $(1977)^{8}$ studies the effect of an abnormal child upon the parents on 30 families with a newborn baby with Down syndrome and 30 families with a normal baby. Both groups were followed for 18 months and were interviewed six times. Few differences could be found in mental or physical health of the two groups of parents, but marital disharmony was found in nine families with Down syndrome and in none of the controls. Beckman (1991) compared stress of 27 mothers and fathers of children with disabilities with the parental stress of 27 mothers and fathers of normal children. The children with disabilities were moderately to severely retarded children. Mothers generally reported more stress than fathers which appear to have different perception of the effect of their child on their lives demonstrated by the different levels of stress on specific sub domain. Jarvis and Creasey $(1991)^{12}$ in a sample of 32 families, found that for both mothers and fathers, parenting stress was significantly related to the insecure attachment of infants. Importantly, the strongest relationships were found between the father's Child Domain scores and insecure attachment in the child. Bruce et al.(2002) ${ }^{3}$ Studied early evidence of behaviour problem in 225 five year old children with or without developmental delays and the relative impact of cognitive delays and problem behaviour on the parents. Result showed parenting stress was higher in delayed condition families. Regression analyses revealed that the extent of child behaviour problems was a much stronger contributer to parenting stress than was the childs cognitive delay. Moran et al. (1992) ${ }^{17}$ in a study reported that mother of developmentally delayed children found their children to be more difficult than did mothers of normal children $(\mathrm{N}=19)$. Their children's cognitive delay was strongly correlated with stress in the child domain. Orr et al. $(1991)^{19}$ employed the PSI to determine the relationship between family stress and coping with the stress on a sample of 86 families with children who were mentally retarded. The researcher found that a greater level of stress was associated with the severity of the child's behaviour problems. In addition, a fewer number of resources were also related to higher levels of stress. Gupta and Kaur $(2010)^{10}$ in a study examined stress among parents of children with intellectual disability. 102 parents formed the sample of this study, 30 of whom had children without disability. This study has two parts physical stress and mental stress. Results show that, most parents of children with intellectual disability experience stress, physical and mental stress are significantly correlated, gender differences in stress experience occur only in the mental area and parents have higher mental stress as compared to physical stress. Holt (1958) ${ }^{11}$ studied two hundred and seven (207) families with a subnormal child living at home in Sheffield found that nineteen percent $(19 \%)$ of the mother exhausted by physical work and emotional stress .Father were said to suffer to a lesser degree but marriages were strained by parental quarrelling

The present study has been undertaken with the aim to assess parenting stress in the parents of mentally retarded children.

\section{METHODOLOGY}

\section{SAMPLE}

A total of 100 respondents (50 parents of mentally retarded children and 50 parents of normal children) were recruited from OPD of RINPAS by using purposive sampling technique. Only those parents were included in the study whose children were in the age range of 5-15 years. Parents either father or mother who were staying with the child were considered for the study. After having informed consent, participants who were able to understand test instruction were taken for further assessment.

\section{TOOLS}

Semi-structured personal data sheet specially designed for study have been used. It contains information about mentally retarded child and parents, socio-demographic variables like age, sex, education, martial status, religion and clinical variables related to child. General Health Questionnaire developed by David and Williams (1988) was administered for detecting psychiatric disorders among respondents in community setting and non psychiatric clinical setting. Reliability coefficient of the questionnaire ranged from 0.78 to 0.95 in different method. Parenting Stress Index Scale developed by Richard in 1983 has been used to assess parenting stress in the parents of mentally retarded children and parents of normal children. This scale is meant for assessing four domains - Defensive Responsiveness, Parental Distress, Parent-Child Dysfunctional Interaction, and Difficult Child.

\section{PROCEDURE}

The study conducted at Ranchi Institute of Neuro Psychiatry and Allied Sciences (RINPAS) Ranchi, Jharkhand. After having informed consent all respondents (parents of both mentally retarded children and normal children) has been selected. Subjects were explained about the objectives of the study then GHQ-12, Parenting Stress Index Scale were administered to the individual subjects far the purpose. 


\section{STATISTICALANALYSIS}

The data obtained have been analyzed by using the computer software program, Statistical Package for Social Science Version 16.0 (SPSS-16.0). Parenting Stress Index Scale has been analyzed by using ' $t$ ' test.

\section{RESULT AND DISCUSSION}

Table : Showing Stress between Parents of Mentally Retarded Children and Parents of Normal Children on Parenting Stress Index Scale.

\begin{tabular}{|l|l|l|l|l|}
\hline Subjects & $\begin{array}{l}\text { Parents of Mentally } \\
\text { Retarded } \\
\text { Children(N=50) }\end{array}$ & $\begin{array}{l}\text { Parents of } \\
\text { Normal Children } \\
(\mathbf{N}=\mathbf{5 0})\end{array}$ & df & t-value \\
\hline Variables & Mean \pm SD & Mean \pm SD & & \\
\hline $\begin{array}{l}\text { Defensive } \\
\text { Response }\end{array}$ & $26.16 \pm 4.81$ & $19.30 \pm 4.25$ & 98 & $7.55^{* *}$ \\
\hline Parental Distress & $44.80 \pm 7.98$ & $30.86 \pm 7.07$ & 98 & $9.24^{* *}$ \\
\hline $\begin{array}{l}\text { Parent- Child } \\
\text { Dysfunctional } \\
\text { Interaction }\end{array}$ & $43.52 \pm 5.63$ & $22.48 \pm 5.48$ & 98 & $18.91^{* *}$ \\
\hline Difficult Child & $46.46 \pm 8.11$ & $25.12 \pm 7.12$ & 98 & $13.97^{* *}$ \\
\hline
\end{tabular}

** Significant at 0.01 level.

It is clear from the table that parents with mentally retarded children showed parenting stress in the area related to Defensive Response in comparison to parents of normal children and difference between these two groups was significant at 0.01 level (PMR: $\mathrm{M}=26.16 \pm 4.81$, PNC: $\mathrm{M}=19.30 \pm 4.25 ; \mathrm{t}=7.55, \mathrm{P}>0.01)$. Further it has been found that parents with mentally retarded children were having feeling that they cannot handle things very easily. They feel trapped by their responsibilities as a parent. There are quite a few things that bother them about their life. They feel that having a child has caused more problems than they expected in maintaining relationship with their spouse. They also found themselves alone and without friends, they were not as interested in people as they used to be earlier. This finding has been supported by Moudgil et al. $(1985)^{18}$ who have concluded that parents of mentally retarded children found to be depressed and aloofish, disturbed marital harmony and interpersonal relationship. Similar trend has also been observed by Majumdar et al $(2000)^{16}$.

It is also noticed that parents of mentally retarded children showed parenting distress in comparison to parents of normal children and difference between these two groups was significant at 0.01 level (PMR: $\mathrm{M}=44.80 \pm 7.98, \quad \mathrm{PNC}: \mathrm{M}=30.86 \pm 7.07 ; \mathrm{t}=9.24$,
$\mathrm{P}>0.01$ ).Further it has been found that parents of mentally retarded children were having feeling that they are unable to do new and different things, they almost were unable to do things that they like to do. They are unable to enjoy themselves in social gathering usually. They also feel like that they don't enjoy things in comparison to parents with normal children. Beckman (1991) ${ }^{1}$, Jarvis and Creasey $(1991)^{12}$ and Sloper et al $(1991)^{24}$ also witnessed similar finding of high level of parental stress in the parents of mentally retarded children.

It is also observed that parents of mentally retarded children showed parenting stress related to parent child dysfunctional interaction in comparison to parents of normal children and difference between these two groups was significant at 0.01 level (PMR:M=43.52 $\pm 5.63, \quad \mathrm{PNC}: \mathrm{M}=22.48 \pm 5.48 ; \mathrm{t}=18.91$, $\mathrm{P}>0.01)$.Further it has been found that parents with mentally retarded children were used to perceive that their child rarely does things for them that make them feel good. Sometimes they feel their child doesn't like them and doesn't want to be close to them. They found that their child smiles much less than they expected. When playing, their child doesn't often giggle or laugh and doesn't seem to learn as quickly as most of the other children. Their child is not able to do as much as they expected and it takes a long time and also it is very hard for their children to get used to new things in comparison to parents with normal children. Finding of the present study is consistent with Jarvis and Creasey $(1991)^{12}$. In their study they have concluded that parents of mentally retarded children show insecure attachment the child. Distractibility, demandingness and unacceptability has been found by Orsmond and Baratt (1999) ${ }^{20}$ and Ricci et al. (2003) ${ }^{22 .}$

It is also seen that parents of mentally retarded children showed parenting stress related to difficult child in comparison to parents of normal children and difference between these two groups was significant at 0.01 level (PMR: $\mathrm{M}=46.46 \pm 8.11, \mathrm{PNC}: \mathrm{M}=25.12 \pm 7.12$; $\mathrm{t}=13.97, \mathrm{P}>0.01)$. Further it has been also found that parents with mentally retarded children were used to perceive that their child seems to cry more often than most children. Their child generally wakes up in a bad mood. They also feel that their child is very moody and easily gets upset over the small things. They also found that their child's sleeping or eating schedule was much harder to establish than they expected. There are some things which child does and that really bother them a lot. Their child turned out to be more of a problem than they had expected and child makes more demands on them than most children in comparison to parents of normal children. 
Similar trend has been observed by other researchers, incompetence, depression, health problems and role restriction (Orsmond \& Baratt,1999) $)^{20}$, day to day struggles of raising a child with mentally retarded (Kravetz et al,1993) ${ }^{15}$, adaptability problem and demandingness (Ricci et al,2003) ${ }^{22}$ perceived difficult child in terms of difficulty in feeding, bathing and dressing (Erickson \&Upshur, 1989) ${ }^{7}$.

CONCLUSION: Parents with mentally retarded children showed stress in the areas related to defensive response, parental distress, parent child dysfunctional interaction and difficult child in comparison to parents of normal children.

\section{REFERENCES:}

1. Beckman, P.J. (1991). Comparision of mother's and father's perception of the effect of young children with and without disabilities. American Journal on Mental Retardation, 95,585-595.

2. Benzur, H. Duvduvancy. I \& Lury, L. (2005). Association of social support and hardiness with mental health among mothers of adult children with intellectual disability. Journal of Intellectual Disability Research, 49 (1), 54-63.

3. Bruce L. Baker, Jan Blacher, Keith A. Crnic, \& Craig Edelbrock (2002). Behaviour problems and parenting stress in families of five year old children with and without developmental delays. American Journal on Mental Retardation, 107 (6), 433-444.

4. Crnic, K.A., \& Greenberg, M.T (1990). Minor parenting stresses with young children. Child Development, 61, 1628-1637.

5. Davies, Martin (2000). The Blackwell encyclopedia of social work. Wiley-Blackwell. p. 245. ISBN 9780631214519.

6. Dyson, L.L. (1997). Fathers and Mothers of school Age Children with Developmental Disabilities : Parental stress, family functioning, and social support. American Journal on Mental Retardation, $102(3), 267-279$.

7. Erickson, M. \& Upshur, C.C. (1989). Care taking burden and social support: Comparison of mothers of infants with and without disabilities. American Association on Mental Retardation, 94, 250-258.

8. Gath, A. (1977). The impact of an abnormal child upon the parents. In R. Peshwaria, D.K. Menon, R. Granguly, S. Roy and A. Gupta (Eds),
Understanding India Families, (37-39) G.A. Graphics, Secunderabad.

9. Guess, L., Pamela, A.F.\& Ellens, S. (1998). Parental Perception of stress and copping: Families of preschoolers with and without disabilities. Dissertation, Abstracts Interventional Section B: The Sciences and Emergency, 59, 0459.

10. Raj Kumari Gupta \& Herpreet Kaur (2010). Stress among parents of children with intellectual Disability Asia pacific Disability Rehabilitation Journal , 21(2), 118-124.

11. Holt, K.S (1958). The home care of severely mentally retarded, Official Journal of the American Academy of Pediatrics, 22, 744-755.

12. Jarvis, P.A. \& Creasey, G.L (1991). Parental Stress, coping and attachment in families with an 18 months old infant. Infant Behaviour and Development, 14, 383-395.

13. Kelso,T., French, D.\& Fernandez, M. (2005). Stress and coping in primary caregivers of children with a disability a qualitative study using Lazarus and Folkman process model of coping. Journal of Research in Special Educational Needs, 5 (1), 314.

14. Krauss, M.W. (1993). Child related and parenting stress. Similarities and differences between mothers and fathers of children with disabilities .American Journal on Mental Retardation, 97, 4, 393-404.

15. Kravetz, S., Nativitz, R.\& Katz,S. (1993). Parental Coping Style and school adjustment of the children who are mentally retarded. The British Journal of Developmental Disabilities Vol. 39, 76, 51- 56.

16. Majumdar M., Rereira, Y.D.D.,\&Fernandes, J., (2000): Stress and anxiety in parents of mentally retarded children. Indian Journal of Psychiatry, 47, $144-147$.

17. Moran, G., Pederson, D.R. Pettit, P. \& Krupka, A. (1992). Maternal sensivity and infant mother attachment in a developmentally delayed sample. Infant Behaviour and Development, 15, 427-442.

18. Moudgil, A. C.,Kumar, H. \& Sharma, S (1985). Buffering effect of social, emotional support on the parents of mentally retarded children. Indian Journal of Clinical Psychology, 2, 63-70. 
19. Orr, R. R., Cameron, S. J.\& Day, D. M. (1991). Coping with stress in family with children who have mental retardation: An evaluation of the double ABCX model. American Journal on Mental Retardation, 95, 4, 444-450.

20. Orsmond, G.I. \& Barratt, M.S. (1999). Mothers and fathers of children with Down Syndrome : Parental stress and Involvement in child care: American Journal of Mental Retardation, 104, 5, 422-436.

21. Peshwaria, R,. Mehinm, D.K., Roy, S. \& Gupta, A. (1995). In understanding Indian families having person with Mental Retardation. Indian Journal for the Practising Doctor, vol. 5, 17-39 (NIMH).

22. Ricci, L.A. \& Hodapp, R.N (2003). Fathers of children with Down Syndrome Versus others type of intellectual disability: Perception, Stress and involvement. Journal Intellectual Disability Research, 47 (4-5), 273-84.

23. Rousey, A., Best, S. \& Blacher, J. (1992). Mother's and father's perceptions of Stress and coping with children who have severe disabilities. American Journal of Mental Retardation, 94, 99-109.
24. Sloper,P., Khussen, C., Turner, S.\& Cunnigham, C., (1991). Factors related to stress and satisfaction with life in families of children with Down Syndrome. Journal of Child Psychology and Psychiatry, 32, 4, 655-676.

25. Upadhyaya, G.R. \& Havalappanavar, N.B. (2008): Stress in parents of the mentally challenged. Journal of the Indian Academy of Applied Psychology, vol. 34, special Issue pp. 53-59.

Authors:

1. Kumari Anjali - M. Phill in Psychiatric Social WORK, RINPAS, Kanke, Ranchi

2. Dr. Jai Prakash - Additional Professor, Department of Clinical Psychology, RINPAS, Kanke, Ranchi

3. Dr. Manisha Kiran - Assistant Professor, Department of Psychiatric Social Work, RINPAS, Kanke, Ranchi.

\section{Corresponding Author}

Dr. Jai Prakash

Additional Professor of Clinical Psychology Department of Clinical Psychology

(RINPAS), Kanke, Ranchi

Cell:09934582290 